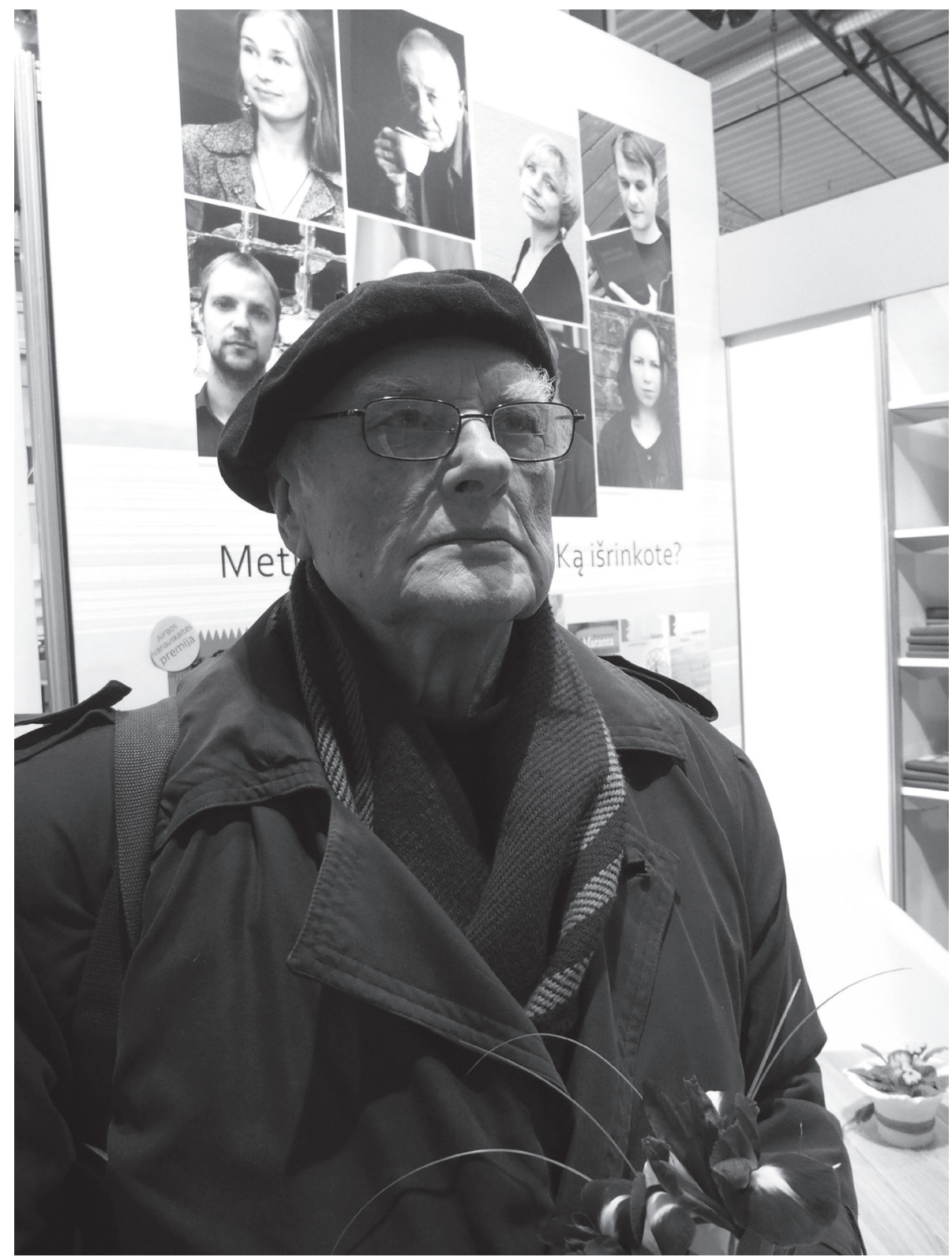

Professor Juozas Algimantas Krikštopaitis.

Photo by Gediminas Zemlickas. 


\section{Born in the Month of Mars: Juozas Algimantas Krikštopaitis - 85}

Juozas Algimantas Krikštopaitis—science historian, philosopher and author of countless books-has turned 85 . There will always be people who believe using birthdays as milestones is somewhat contrived but when is there a better time to say a few glowing words about this worthy man of science? In any case, the "culprit" behind this occasion has nothing to do with it because such a day comes uninvited. Krikštopaitis was born on the $13^{\text {th }}$ day of the month of Mars (mensis Martius), the Roman god of war, which means it was preordained from above that this man was to accomplish great feats. And all of this came true, perhaps not in the Field of Mars itself, but first and foremost in the field of science. And it could not have turned out any better for us. Lithuanians are proud to have descended from the ancient Romans and often find occasions to remind others of this. It might be a bit strange, but they chose to call the first month of spring kovas and not name it after Mars, the god of war, himself. Kovas or kovarnis is the Lithuanian word for rook, one of the first birds to return to our homeland each spring. Perhaps this was a meaningful choice after all, for the root of this word is related to warlike words such as kova (Lith. 'fight', 'combat', 'battle'), kovingas ('combative') and kovotojas ('fighter', 'combatant', 'champion'). Thus, our nature-worshipping and no less combative forefathers were not far off the mark.

He was very close to being named after the warlike Vytautas, all he would have needed to do was be born a single year earlier, in 1930. Lithuania commemorated the year of Vytautas Magnus with great energy, and the majority of boys born in that year were christened after Vytautas, the nation's great hero and the Grand Duke of Lithuania. There is little doubt that the man we speak of would have been named so as well. Born in 1931, he still received the name of a duke together with his Christian name. Some believe that the fate of a man is sealed within their name. The name Algimantas is composed of two roots: alg- and mant-. The first refers to alga (Lith. 'pay', 'salary'), atlygis ('reward'), atpildas ('comeuppance', 'reward'), and the second, mant-, is the root of mantùs, a synonym for sumanus ('resourceful', 'clever'). Mantà can also mean one's belongings, one's property and one's wealth. To what extent is this reflected in the life of our honourable professor? No questions rise as to his resourcefulness, but as to his 
property... Nothing of note, unless we consider his intellectual property and his spiritual wealth, which came in the form of the many books and articles he had written, the conferences and symposiums he had organised in Lithuania and abroad, as well as the various lectures he had read to the students of Lithuanian universities. This broad range of activity, underpinned by a social drive, did not help the scientist accumulate material wealth, but it did earn the priceless recognition of the public and his peers.

At least two Lithuanian philosophers-Naglis Kardelis and Krescencijus Stoškus-referred to J. A. Krikštopaitis as a renaissance man in their publications. Of course, not as an advanced payment, but for the work he had already accomplished. Is this not the greatest reward for a man christened with the Christian name of Juozas (Joseph) and the old Lithuanian name of Algimantas? And they say that Lithuanians are not inclined to spare good words for one of their own.

Krikštopaitis's road into the meadows of the philosophy and history of science was rather winding, but apart from slowing his step, these winds also brought him to new discoveries. In the eyes of most people that know him, he is a prominent humanist and it is difficult to imagine him measuring the spontaneous deformation of silicate monolith at the laboratory of the Institute of Architecture and Construction. But it is this institute that saw the beginning of his academic endeavours - this was where he wrote his first dissertation, where he defended it in 1962 and earned his $\mathrm{PhD}$ in technical science. A completely natural subject for a chemical engineer, but what brought him to this stretch of the woods when his heart was drawn to the humanities? In order to understand this, we should stick to some sort of consistent narrative.

His choice was determined by more than his natural inclinations-it was also a consequence of a healthy pragmatism and the patriotic values instilled by his parents. The latter were shaped by a special historical environment, one in which the unique phenomenons of book smuggling, vargo mokyklos (unofficial schools, Lith. 'schools of hardship'), the secret distribution of Lithuanian books and barn theatres were a part of life, and by previously undreamed-of opportunities that opened up to Lithuanians with the restoration of Lithuanian independence in 1918. During World War I, his mother, Mykolina Obelenyté (Krikštopaitienè), found herself, along with an entire wave of refugees, in the depths of Russia, in the town of Voronezh, where she completed a Lithuanian teaching course and worked as an educator for the rest of her life. His father, Bronius Krikštopaitis, acquired the diploma of a long-distance marine captain in Finland and went 


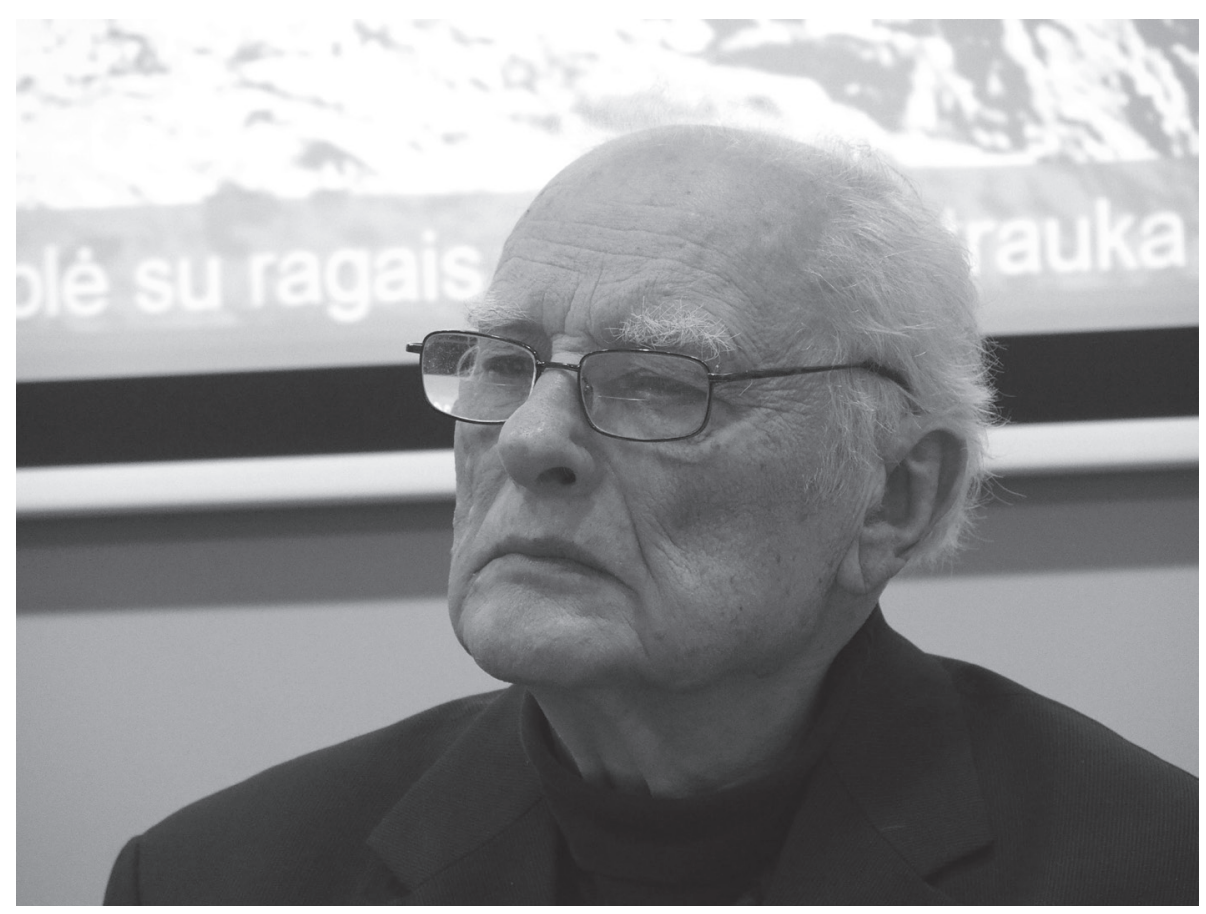

Professor Juozas Algimantas Krikštopaitis.

Photo by Gediminas Zemlickas.

on to become the first Lithuanian sea captain and one of the founders of the Lithuanian maritime fleet. As World War II drew to a close, he was forced to flee the country and settled in the U.S.A., where he died and was buried in 1999. There is no doubt that this fact had a critical impact on his son. Graduating from the Saule Secondary School, he chose the profession that was least affected by ideology-engineering. This decision was supported and probably influenced by his mother, who was living proof of the fact that a professional working in the humanities under Soviet rule could in no way avoid getting involved in politicised activity.

In 1949, Juozas Algimantas was accepted as a student at Vytautas Magnus University, but graduated from the Faculty of Chemical Technology at its newer reincarnation, the Kaunas Polytechnical Institute, in 1954. As I have mentioned already, at the Institute of Architecture and Construction, Juozas Algimantas studied the properties of silicates, and in 1965, as a Doctor of Engineering, he began to work at the Academy of Science Institute of Physics and Mathematics (restructured as the Institute of Physics from 1977), and later transitioned into 
the Institute of Semiconductor Physics. This wandering from one institute to another might be misunderstood by some without any explanation. At the Institute of Architecture, Krikštopaitis practically researched the properties of silicon compounds under high temperatures and pressures. However, his subject had to be linked to the subjects researched at the Institute of Architecture, and due to conjunctural requirements, his dissertation had to be formally wrapped into the subject of the problematics of concrete. At the time, Lithuanian physicists working with semiconductors were investigating silicon and germanium monocrystals, making Krikštopaitis's move to the physics department a natural one. He dove head first into the activity of Juras Požèla's group of researchers (as if he had been preparing for it all this while), which was focused on issues related to the physical chemistry of semiconductors.

For thirteen years, he researched physical and physicochemical phenomena in various materials. Let us take note of one of these phenomena: in 1970, while taking an in-depth look at the chemical redox reactions on the surface of germanium monocrystals, Krikštopaitis discovered a previously unnoticed generation of unbalanced charge carriers. He observed this phenomenon when an oxidation-reduction reaction took place as the crystal came into contact with a liquid. A similar effect is produced by a narrow beam of intense light directed at the surface of the monocrystal. This work was published in the prestigious Soviet academic journal for chemical research Электрохимия (1971, vol. 7, no. 10, pp. 1579-1581). Krikštopaitis received recognition for the effect he had discovered and he was invited to various conferences and even events abroad. However, he was not allowed to participate in international symposiums because the Sword of Damocles hung over his head-his documents were stamped as nevyezdnyj — without the right to travel abroad. The scientist's personal biography did not meet the requirements of the ideological regime of the time. His personal contacts with foreign scientists were limited and he had no access to information that was critical to his further research. Three decades passed and the German scientist Gerhard Ertl was awarded the Nobel Prize in Chemistry for his research on a similar subject in 2007. In addition to this, Krikštopaitis was forced to refuse the invitation to join the research group of the famous physicochemist Prof. Heinz Gerisher (Ertl's academic advisor for his dissertation) on the very same grounds. The drama of the scientists working in this small country is a relevant subject for science historians, for this was a time when opportunities and international recognition was determined not by talent and hard work, but by altogether unrelated reasons. Some light has been shed upon this topic by Professor Romualdas Šviedrys (U.S.A.). 
At the same time (the beginning of 1970), when Krikštopaitis was successfully delving into his research of redox reactions, we can observe the first clear turning point in his biography towards his true calling-the humanities. From 1972, he began participating in the activity of the natural science and technology history research club organised by Professor Paulius Slavėnas. In 1978, Krikštopaitis was offered to join a science philosophy research group being created at the Lithuanian Science Academy's Institute of Philosophy, Sociology and Law. This new turning point in his life finally set him on the path of research into the history and philosophy of science. At the Institute, Krikštopaitis led the Humanist Philosophy Department and began writing his second dissertation, only this time for the degree of a Doctor of Philosophy. From 1982 to 1986, he attended lectures at the Moscow State University, the Institute of Philosophy of the U.S.S.R. Academy of Sciences (AS) and the U.S.S.R. AS Institute of History of Natural Sciences and Technology in Moscow. In 1989, he defended his second dissertation on 'The Evolution of Concepts on the Materiality of Matter: a Historical-Methodological Analysis'. After nostrification in 1993, he was awarded the degree of a habilitated doctor (of the humanities, philosophy) and later granted the title of Professor.

It is interesting to note that even after becoming a legitimate philosopher, he did not always find common ground with his peers. This was not so much the result of differences in character, but rather differences in approach towards the subject of research. The majority of philosophers typically applied the criteria of an education in the humanities to the subjects of their research, but having acquired the profession of a physicochemical engineer, Krikštopaitis based his work on the criteria of scientific research. Perhaps it was for this reason that he got along better with science historians and Western science philosophers. Incidentally, he did not consider the scientific approach in absolute terms. According to Krikštopaitis, without a sufficient foundation in the humanities, apologists for the natural sciences risk slipping into the ranks of technocrats. The key term here is harmony-a synonym for the golden ratio. And that is what he strived to achieve. Thus, to put it shortly, our honourable subject had a natural inclination toward the humanities and a strong scientific background. Herein lies his strength as both a philosopher and science historian.

Perhaps it was this set of qualities that caught the attention of astronomer and science historian Paulius Slavènas. Founded in 1950, his science history club developed into the Lithuanian Society of Science Historians and Philosophers. He became its first chairman and practically trained his successor. After Slavènas's 
death in 1991, Krikštopaitis took up his honourable duties. The latter made significant contributions to the organisation of science history conferences and the further development of the field in the Baltics. Back in Soviet times, these forums had become places of free thinking and even the expression of a national identity-something one would find difficult to believe. This was, of course, first and foremost the result of the efforts and reputation of two Latvian giants in the scientific world-medic and clinical oncology pioneer Pauls Stradiñ̌š, (1896-1958) and his son, organic chemist Janis Stradinšs. The work of these two academicians deserves a separate and comprehensive article (better yet, a monograph), but today all we can say is that Lithuania does not currently have figures of such prominence and far-reaching influence and probably will not have any for some time to come. They were also some of the most important organisers of the first Baltic conference of science historians, which took place in Riga on 6-7 June 1958.

In 1987, during an informal meeting, the heads of science history in the Baltic countries decided to continue developing their ideas and to risk leaving the Soviet National Union of the Historians of Science and Technology which up to then had coordinated the activity of the science history societies of the Baltics. We will not get into detail on how subtly and diplomatically Mikhail Gorbachev's restructuring policies were used to establish the Baltic Coordinating Council for Science Historians, which marked the beginning of the path to independence for the science historians of the three states. On 10 February 1988, thanks to the efforts of Janis Stradiňš, the Coordinating Council was approved by the Presidium of the Latvian Academy of Science, shortly followed by the Estonian Academy of Science. The Lithuanian Academy of Science adopted an analogous decision upon the initiative of Slavenas, patriarch of the country's science history, and Krikštopaitis, the de facto leader of the Society of Science Historians.

Only the final step had to be taken. On 19 May 1988, scientists and academicians gathered for the plenum of the Soviet National Union of the Historians of Science and Technology in Moscow. As he was given the floor to speak, Janis Stradiňš announced that based on the decisions of the three Baltic academies of science, the Baltic Coordinating Council for Science Historians would henceforth be in charge of managing the activity of the science historians of each respective Baltic state, and maintain traditional relations with the science historians of the other Soviet republics. The 29 October 1990 marked the foundation of an independent Association of the History and Philosophy of Science of the Baltic States. Janis Stradiň̌̌ (Latvia) became the organisation’s first president and Juozas 
Algimantas Krikštopaitis (Lithuania) and Karl Siilivask (Estonia) its first vice presidents.

This was, in fact, the beginning of a new era in Baltic science history and its significance is difficult to overestimate. On 4-6 October of that same year, the $16^{\text {th }}$ conference of the science historians of the Baltics, organised by Krikštopaitis, took place in Vilnius. On 22-29 September 1993, the $19^{\text {th }}$ world congress of science historians took place in Saragosa (Spain), and the Association of the History and Philosophy of Science of the Baltic States, represented by vice-presidents Krikštopaitis and Siilivask, was accepted as a member of the International Union of the History and Philosophy of Science (IUHPS/DHS).

As Lithuania returned to the path of an independent nation's development, Krikštopaitis became a member of Vytautas Magnus University's (VMU) Reconstituent Senate. He felt a sense of moral satisfaction having the opportunity to apply his experience in an original course entitled the Humanist Foundations of Science. He taught this course on the importance of an education in the humanities to engineers for two decades at VMU and the Kaunas University of Technology (KTU), where he participated in the development of various graduate and post-graduate programmes, as well as to grad school students at the Vilnius Pedagogical University (now the Lithuanian University of Educational Sciences), and episodically in Riga and Tartu.

For several years, Krikštopaitis attempted to establish a graduate course in the history and philosophy of science. However, it turned out that Lithuanian universities had no need for such a programme. Even KTU met his idea with scepticism: they might be teaching this abroad, but that does not mean it will work in Lithuania... Having accepted the fact that he would not get his way without some diplomatic manoeuvring, Krikštopaitis came up with a clever trick. He used the support of Romualdas Šviedrys, who to this day teaches subjects in the history of science at the Brooklyn Polytechnic Institute of New York University, and introduced him to the rector of KTU in 1999: here was a man with great international experience who was willing to participate in their programme... Now they were talking. The graduate programme was given green light and things started to move in the right direction. In recognition of Romualdas Šviedrys's honourable work, we must mention that he was wholeheartedly involved in the project and made around 40 privately-funded trips from New York to Lithuania to read his lectures, even though he was never rewarded for his efforts. Even his Lithuanian citizenship has not been reconstituted, even though the seven-year-old Šviedrys and his parents were forced to flee their home town 
of Kaunas in 1944. We can only rejoice in the fact that Romualdas Šviedrys was recognised with the title of honorary doctor of KTU in 2004, and awarded with the Soldier's Cross 'For Contributions to Lithuania' in 2010. It is a pity that the new master's programme was discontinued after 2004, for entirely trivial reasons: shortcomings of the study system and bureaucratic obstacles.

Working at the Institute of Philosophy, Sociology and Law (later renamed the Lithuanian Culture Research Institute after several restructuring procedures) gave Krikštopaitis a sense of creative freedom and did not interfere with his broad range of social activities. Krikštopaitis worked as the senior researcher at the institute up to 2011, and has led the Lithuanian Society of History and Philosophy of Science up to the present day. He has also received recognition as an organiser in the scientific community in Lithuania. Since 1994, he has organised the annual Scientia et historia conference dedicated to the history and philosophy of science, and he has become an honorary member of the Latvian and Estonian associations of history and philosophy of science. He was invited to organise symposiums for the World Congress of Science Historians in Mexico (2001), Beijing (2005) and the international conference of the European Society for the History of Science in Vienna (2008).

The most fruitful years of Krikštopaitis's life are related to the history of science. $\mathrm{He}$ is the author of 14 books (11 monographs, two of which were written with co-authors), 300 academic articles and just as many popular articles and essays promoting science. It would be wrong to separate Krikštopaitis's scientific and social work into two stages: before 11 March 1990 and after it, with the restoration of Lithuanian independence. His view of the world never changed, for in his heart Lithuania was always the same, always independent. However, it should be said that new opportunities for expression emerged under the conditions of freedom, especially in the Lithuanian humanities, that had previously been impossible due to political censure. The change in Krikštopaitis's range of academic interests is reflected in the books that he wrote. In 1984 and 1986, he published A Classical Conception of Materiality (Lith. 'Klasikinè medžiagos koncepcija') and Physical Reality from the Quantum Perspective (Lith. 'Fizikine realybe kvantiniu aspektu') in Russian.

With the restoration of Lithuania's independence, Krikštopaitis began to focus more attention on the subjects of statehood, civic duty and culture, as well as to contemplate the new challenges arising from newly restored statehood and globalisation. Titles of his books include: Saugi valstybè: idejja ir tikrove ('A Safe State: Idea and Reality', co-authored with A. Rimaite, 2004), Pasakojimu 
sandara: Struktūrine tikrovę aiškinančiu tekstų interpretacija ('The Composition of Tales: Interpreting Texts Explaining Structural Reality', 2006), Nepakartojamos akimirkos: susitikimai su kultūros kürejais ('Remarkable Moments: Meeting Cultural Creators', 2011), Išmintis, atsiverianti pažinimo kelyje ('Wisdom on the Path to Learning', 2013), Neiveikiama teatro galia ('The Invincible Power of Theatre', 2014), Istorijos veju pagairejje. Lietuvos mokslo ir švietimo raidos bruožai ('Windswept by History: Features of the History of Science and Education in Lithuania', 2015, co-authored with L. Klimka).

Of the professor's books on the history of science, the monograph Ahead of Time: Theodor Grotthuss (2001) is especially worthy of note. The publication is dedicated to Theodor Grotthuss (1785-1822), a physicochemist, the creator of the first theory on electrolysis and discoverer of two fundamental rules of photochemistry, and perhaps the most widely known scientist associated with Lithuania. It is interesting that as he was researching the phenomenon of redox, Krikštopaitis discovered the initial research results of crystal dendrite growth described by Theodor Grotthuss. This was when the professor developed an interest in this historical figure. It was Grotthuss that brought him into a closer acquaintance with Janis Stradiňš. Krikštopaitis's monograph seemingly served as a continuation of Janis Stradinšs study of the great scientist, the first in the world, published in Russian in 1966. The Latvian scientist focused foremost on Grotthuss's work in the field of chemistry, whereas Krikštopaitis was more concerned with revealing his multi-faceted nature and presenting what his predecessor had left relatively unstudied. Krikštopaitis's new book on Grotthuss is currently being prepared for publication. This will be a second revised edition with additional research material. Latvian scientists are translating the text, which will soon be published in Riga.

Krikštopaitis has met the month of Mars in the year of his $85^{\text {th }}$ birthday with two new books. One book-Iskiliu asmenybiu gyvenimo tiesa ('The Truth of the Lives of Prominent Figures')—is written by himself, and the other is a memoir by his father, long-distance captain Bronius Krikštopaitis-Jüru keliais ('On the Ways of the Sea'). It was previously published in 1979 in Chicago, where Lithuania's first maritime captain lived and died as a reluctant emigrant in 1999. Now, thanks to his son, his book will be published in Lithuania as well. Thus, the son has fulfilled a double duty: honouring the memory of his father and allowing Lithuanian readers to learn about this significant period of Lithuanian history, when after the restoration of independence the first Lithuanians found the determination to prove that even their hands, so accustomed to peasants' 
work, could take charge of seafaring vessels.

Precisely ten years ago, Krikštopaitis published a book entitled Albina Makünaité: dramatine dailès poetika ('Albina Makūnaitè: The Dramatic Poetry of Art', 2006). This was a book dedicated to his wife. Albina Makūnaitè (1926-2001), who was a well-renowned Lithuanian graphic artist, the participant of countless exhibitions, a famed book illustrator, laureate of the Lithuanian State Prize, a worthy figure in the world of art and a folk artist.

The last few books we have highlighted lead us to transition to our concluding statements. It is clear that the man we speak of has an acute sense of personal responsibility. Not only for his family and his close ones, but for the fields of science to which he dedicated his creative energy and capabilities. He cares about what is happening in Lithuania's theatres, art scene, and our ever more fast-paced lives. For a man of renaissance range, there is no other way. Incidentally, the professor would probably correct us with an ironic smile-a non-renaissance man. He experienced encounters with the imperfections of daily life, the short-sightedness of authorities and obvious mistakes with great emotion. Sometimes he lacks the Socratic seriousness that is so crucial for the philosopher: he can be hot-tempered, gesture with energy and express anger and throw very fitting admonishments in the direction of bureaucrats of every kind, even though he knows that this will not change anything, perhaps just allowing him to vent some steam. Unfortunately, it is not in the power of philosophers to turn the world on its axis. Then one is left with no choice except to vent in a new essay or article. This is the constant drama of the intellectual: being able to see, to understand and not being able to change it all. Only one escape remains - the escape of creativity. For Krikštopaitis, the history of science is a never-ending and intriguing adventure full of dramatic turns of thought, when scientific analysis and the intuition of a humanist reveal unexpected avenues of thinking and creative activity, opening up new horizons of learning that excite the imagination. His work and lifestyle are what set him apart as a science historian of the highest calibre.

He had long arrived at the realisation that any kind of creative output is part of culture, and science, for him, is also a cultural phenomenon. This belief was probably influenced by Vytautas Kavolis, sociologist and professor of comparative studies of civilisation-and admitting this is no shame. It is in culture that the man of the hour finds inspiration as a scientist with great range. Perhaps this is his way of relaxing or finding a way to keep his spiritual equilibrium. What else, if not nature and culture, can remind a world so set on modernising at a 
breathtaking pace about the brakes that it needs so badly in order to maintain a certain sense of stability in the only life we are given. After all, this is not a field for experimentation.

These are the thoughts that come to me as I contemplate the 20 years that I have known or even collaborated with the honourable Juozas Algimantas Krikštopaitis. I wish him nothing but good health, and the rest will come by itself.

\section{Gediminas Zemlickas}

Translated by Justinas Šimkus, HESI GROUP, UAB 